\title{
Re-examining Shell-Tempered Chickasaw Pottery in Post-contact Mississippi, USA
}

\author{
Domenique C. Sorresso ${ }^{1,2}$ and Patrick S. Quinn ${ }^{2}$ \\ ${ }^{1}$ Department of Anthropology, University of Florida, Gainesville, FL, USA \\ ${ }^{2}$ Institute of Archaeology, University College London, 31-34 Gordon Square, London WC1H \\ OPY, UK
}

\begin{abstract}
Archaeological and ethnographic records indicate that a change in Chickasaw ceramic technology from recent to fossil shell temper took place around the time of contact as populations migrated north and adjusted to their new upland settlements on the Blackland Prairie, Mississippi, USA. While the occurrence of this technological shift is widely accepted within the archaeology of the region, it can be difficult to apply to ceramic assemblages as clear criteria with which to distinguish between the two tempering modes is lacking. This study re-examines the phenomenon of Chickasaw shell-tempered ceramics and sheds new light on the proposed shift by analyzing macroscopically and scientifically 63 pre- and post-contact sherds from three sites in northeastern Mississippi. By applying a materials science perspective, including thin section ceramic petrography, X-ray fluorescence spectroscopy, and scanning electron microscopy, it was possible to differentiate between recent and fossil shell inclusions, recognize the coexistence of these two types of temper, and further group shell-tempered Chickasaw sherds based on the presence of other inclusions. The raw materials, provenance, and manufacturing technology of the detected compositional groups were then interpreted in terms of local traditions of ceramic manufacture and the movement of native people and their pottery in the post-contact period of Mississippi. This study also addresses the difficulties of macroscopic identification and its implications for using the temporal shift as a method of relative dating.
\end{abstract}

Keywords: Pottery; Native American; Chickasaw; Shell tempering; Compositional analysis; Thinsection petrography; Ceramic technology

\section{Introduction}

The arrival of the Spanish conquistador Hernando de Soto and his men in Mississippi, USA in 1540 A.D. set into motion a chain of events which left a 'shatter zone' of regional instability in its wake (Ethridge 2009, p. 21). This was initiated by the accidental spread of disease that began with de Soto and continued with the establishment of slave trading in the $17^{\text {th }}$ century which affected many of the Native American groups that called the area their home. The modern-day Chickasaw were one of the new societies that were born out of this turmoil (Etheridge 2009). 


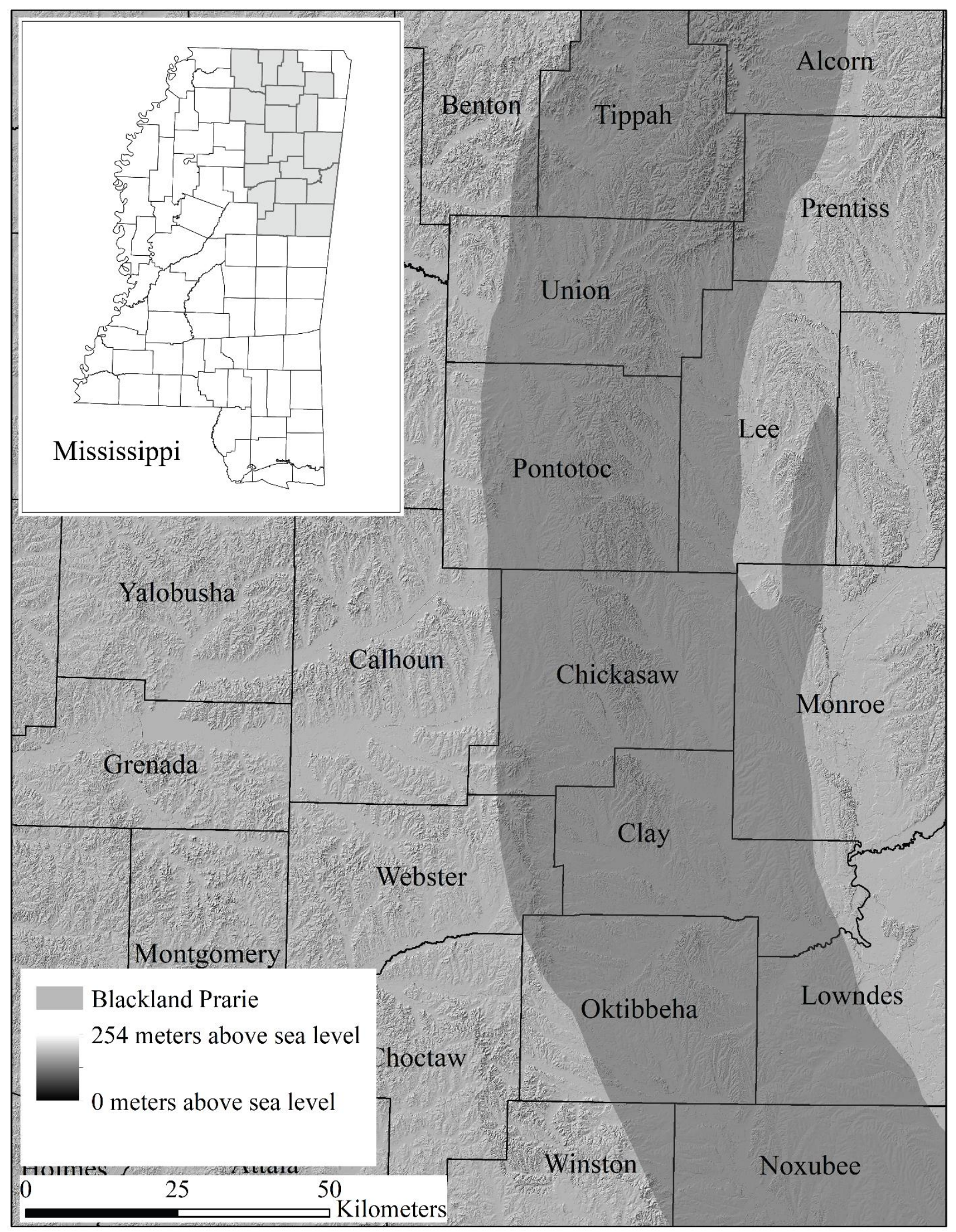

Figure 1. Map of northeastern Mississippi, USA with the locations of Oktibbeha County and the Blackland Prairie. 
Around this period of initial European contact, the Chickasaw people, who once inhabited moundcenters along the Tombigbee River and its tributaries, migrated to the grassland ridges of the upland Blackland Prairie region. The Blackland Prairie is a 300-mile belt of temperate forests that stretches from southern Tennessee to northeastern Mississippi and Alabama (Ethridge 2010, p. 75) (Figure 1). Archaeological records also indicate the existence of a cultural upheaval and changes in craft traditions, including ceramic practices. The literature describes a switch from the use of recent freshwater shell temper in the pre-contact Mississippian (A.D. 1000-1540) and early contact periods (A.D. 1540-1650/1699) to the addition of fossil shell favored by the post-contact Chickasaw (Ethridge 2010, p. 75; Lowe 1920).

This perceived technological shift in tempering practices has been used alongside decorative attributes to classify typologically the largely fragmented Chickasaw ceramics that occur at archaeological sites in Mississippi and serve as a relative dating tool (Atkinson 1987; Rafferty 1995). Sherds identified as being tempered with recent shell are assigned to the Mississippian and early contact periods, those thought to be tempered with fossil shell are dated to the later post-contact period (1650/1699-1750 A.D.) (Atkinson 1987; Johnson et al. 2008), and ceramics tempered with sand are ascribed to the late eighteenth century onwards (Lieb 2004). Pre-contact Mississippian ceramics are often decorated with incisions, punctations, and appliqués, while the post-contact material is predominantly plain (Johnson et al. 2008; Lieb 2004).

Despite its widespread acceptance in the archaeology of the region, the shift in temper from recent to fossil shell can be difficult to apply to specific ceramic assemblages due to the small size of the inclusions and a lack of established criteria for distinguishing between these two types. This may have led to the incorrect dating of sites and errors in documenting the proposed shift in ceramic technology. The exact differences between the two shell temper types have never been systematically described and an in-depth study is therefore needed in order provide clarity.

In order to address this issue, the present paper investigates via macroscopic, microscopic, and elemental analysis, pre- and post-contact pottery sherds from three sites in Oktibbeha County, Mississippi. It seeks to independently classify the ceramics and thus test the perceived differences between the 'Recent Shell', 'Fossil Shell,' and 'Fine Sand' types. The resulting compositional groups have been characterized in terms of the types and sources of raw materials they were made from, as well as aspects of their manufacturing technology. This data is used to examine the locations and traditions of Chickasaw ceramic production, particularly the proposed shift from the use of recent shell to fossil shell, as well as the movement of native people and their ceramics within the region. In the light of this information, we review the current methods of temper identification in the region and propose possible means of improvement.

\section{Archaeological Sites and Samples}

The sites analyzed in this study, Stark Farm, Lyon's Bluff, and Rolling Hills, are all located on the Blackland Prairie in present-day Oktibbeha County, Mississippi (Figure 1). This region is characterized geologically by the Upper Cretaceous Selma Chalk Group (Lowe 1920, p. 11) (Figure 2), which includes the Demopolis Chalk, Ripley, and Prairie Bluff Chalk Formations, and the Midway Group, which includes the Porters Creek, Clayton, and Naheola Formations. These formation 
groups are composed of calcareous clay, chalk, sandy chalk, gray to greenish-gray fine glauconitic sand, and sandy limestone (Moore and Bicker 1969).

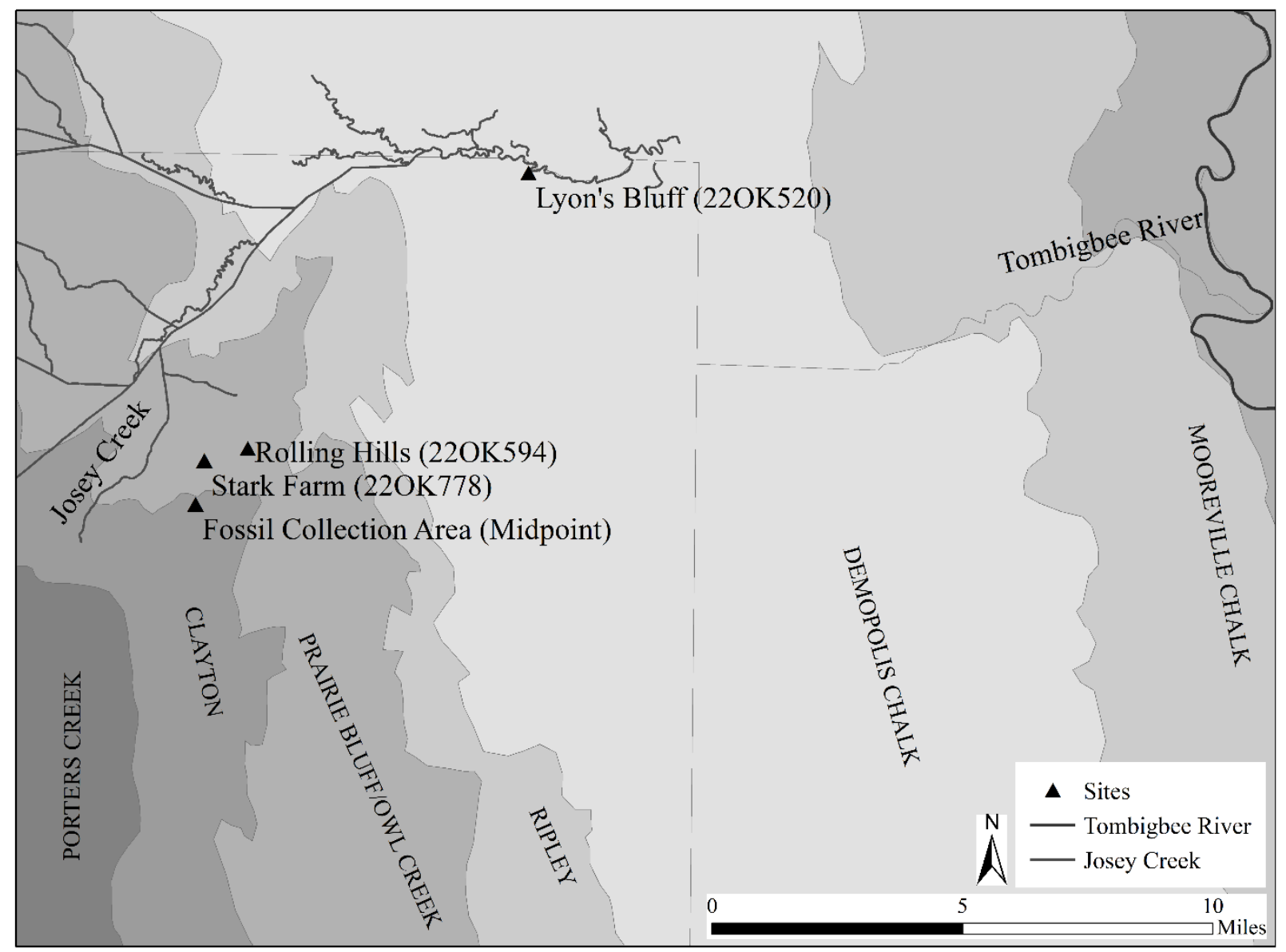

Figure 2. Generalized geological map of northeastern Oktibbeha County, Mississippi, USA with the location of the sites analyzed in this study and collection areas of the comparative material. Based on Moore and Bicker (1969).

Recent excavations at Stark Farm (22OK778) indicate a late Mississippian to early contact period chronological position based on the association of early European metal with diagnostic ceramic types and radiocarbon dates that suggest the site was likely inhabited between A.D. 1425-1670 (Cobb et al. 2016; Smith 2017). Cobb et al. (2016) conducted a preliminary study of the ceramics excavated in 2015 during the initial survey and excavation, and Smith (2017) studied the ceramics excavated during the 2016 field season, including the sherds analyzed in this study. Lyon's Bluff (22OK520) consists of a single mound Mississippian village site. Although relatively little has been written about the excavations at the site, several studies have been conducted concerning the provenance, frequency seriations, and absolute dates from the site (Peacock 2002; Peacock and Hogue 2005; Peacock et al. 2007; Peacock et al. 2010; Rafferty and Peacock 2008, 2009). The radiocarbon dates of several burials and features produced by Peacock and Hogue (2005) indicate that the site was inhabited between 1200 and 1650 A.D., which places it within the late Mississippian and early contact periods. Rolling Hills (22OK594) is one of several small Mississippian to 
early contact period farmsteads that were salvaged by archaeologists from Mississippi State University in the 1970s (Hogue 2000; Trinkley 1994). Radiocarbon dates and European artifacts recovered from the sites indicate an extensive occupation from A.D. 1450-1800, although the radiocarbon date ranges and artifact assemblages suggest many of the burials may date to the $17^{\text {th }}$ century (Hogue 2000).

A total of 63 ceramic sherds were selected from the three sites, including 25 from Stark Farm, 20 from Lyon's Bluff, and 18 from Rolling Hills (Table 1). These were assigned analytical codes MSC001-MSC063 (Mississippi Ceramics). The Stark Farm sherds originate from four large Chickasaw pit features uncovered during two block excavations, in which most of the ceramics were found in the first level. Ceramic cross mends between feature zones and the relatively homogeneous soil profiles suggest that each feature was the result of a single depositional event (Smith 2017). The artifacts from Lyon's Bluff came from multiple test units spanning three stratigraphic zones of a midden deposit, with the exception of two surface collected sherds. Peacock and Hogue (2005) note that there is no apparent correlation between calibrated radiocarbon dates and the depth of corresponding burials at Lyon's Bluff, calling into question the use of arbitrary levels to understand the temporal placement of materials. All sherds from Rolling Hills were amassed during surface collection.

The majority of ceramics from all three sites consisted of small undecorated non-diagnostic body sherds with little indication of the original form of the parent vessels they came from. The 63 selected sherds were already classified typologically by the respective donating institutions according to their temper type as either Recent Shell, Fossil Shell, or Fine Sand. Examples of the first two types occur at all three sites but only two of the sherds, both from Stark Farm, were attributed to the Fine Sand category. The sherds were further classified via the type-variety system, using their surface treatment and decoration (Blitz 1993; Mann 1983) (Table 1). Although stratigraphic information is available for selected sherds in the assemblage, complexity of these sites makes it difficult to understand changes in the ceramic chronology using depth.

\section{Analytical Methods}

All samples were visually examined with a low-power reflected light microscope, paying attention to the nature of their macroscopically identifiable inclusions. An attempt was made to understand their macroscopic attribution and detect criteria that might be used to distinguish between the Recent Shell and Fossil Shell types. Ceramic petrography was then used to investigate in more detail the fabric composition of all 63 ceramic sherds in terms of their raw materials and manufacturing techniques. Thin sections were prepared using a modification of the standard geological technique. These were examined under a polarizing light microscope at magnifications of 50-100x and grouped into fabrics or recipes based upon the nature of their non-plastic inclusions, clay matrix, and voids (Quinn 2013, p. 73-102). The identified petrographic fabrics or recipes were then described using a modification of the system proposed by Whitbread (1989). Prior to thin sectioning all sherds were analyzed via portable x-ray fluorescence spectroscopy (pXRF) in order to characterize their bulk geochemical composition. The surfaces of the ceramics were abraded with silicon carbide paper to remove any surface contamination. Due to the sampling issues posed by the heterogeneity of coarse ware sherds for pXRF characterization (Tykot 2016), we analyzed two or 
more c. $1 \mathrm{~cm}$ diameter circular spots per sherd then averaged the results for each element. Irradiation was performed with an Olympus Innox-X Delta Premium hand-held device using a Rh source and a $2 \mathrm{~mm}$ Al filter. Analysis was undertaken at $40 \mathrm{kV}$ for 120 seconds live time. The Bruker ARTAX software was used to deconvolute the spectra, and the curved shape of sherds was adjusted for with a Rayleigh scatter distance correction. The generated net counts were converted into concentrations using a bespoke in-house calibration for 15 elements $(\mathrm{Ca}, \mathrm{Co}, \mathrm{Cu}, \mathrm{Fe}, \mathrm{Ga}, \mathrm{K}$, $\mathrm{Mn}, \mathrm{Nb}, \mathrm{Pb}, \mathrm{Rb}, \mathrm{Sr}, \mathrm{Ti}, \mathrm{Y}, \mathrm{Zn}, \mathrm{Zr}$ ) that was created for ceramics with high percentages (>8\%) of calcium (Burton et al. 2019; Wilke et al. 2017). The capability of the device and the in-house calibration was evaluated by analyzing 14 powdered certified reference materials, including ore, sediment, rock, and ceramic, using those values that fall within the range found in low-fired archaeological ceramics (Appendix 1), as well conducting repeat measurements on a single standard (SARM69 - Brick Clay) at the start of each session. The latter indicated that the pXRF device had a high level of precision for most elements ( $<5 \%$ coefficient of variation). Eight of the analyzed elements (C, Fe, K, Ti, Rb, Sr, Zn, and Zr) were found to have an acceptable accuracy of $15 \%$ relative error or less (Appendix 2). The raw concentrations of these elements were subjected to principal components analysis (PCA) and bivariate scatterplots in order to detect and understand multivariate elemental patterning within the ceramic dataset. We then compared this data to the typological and petrographic classifications as well as the sites from which the sherds were excavated.

Selected sherds from several petrographic fabrics were analyzed under a Zeiss Evo 25 scanning electron microscope with an Oxford Instruments X-Max 80 energy-dispersive X-ray spectrometer in order to investigate the chemistry of the inclusions and clay matrix. Samples were mounted in resin, polished down to $1 \mu \mathrm{m}$, and coated with carbon, before being studied with an operating voltage of $20.0 \mathrm{kV}$ and a working distance of $8.5 \mathrm{~mm}$. Elemental characterization was undertaken at 1000x magnification for a live time of 20 seconds per point and an average dead-time of $40 \%$. An in-house calibration was applied to generate compositional data via stoichiometry with the Oxford Instruments AZTEC software. The data was exported in normalized oxide weight percent and calculated stoichiometrically. Data quality was monitored using three basalt standards (BHVO, BCR, and BIR) (Appendix 3). This indicated that $\mathrm{Al}_{2} \mathrm{O}_{3}, \mathrm{CaO}, \mathrm{MgO}, \mathrm{SiO}_{2}$, and $\mathrm{TiO}_{2}$ could be measured with an accuracy of $6 \%$ relative error or less, but the data quality of the lighter oxides, $\mathrm{K}_{2} \mathrm{O}, \mathrm{Na}_{2} \mathrm{O}$, and $\mathrm{P}_{2} \mathrm{O}$, was poorer. The $\mathrm{FeO}$ oxide weight percentages were converted to $\mathrm{Fe}_{2} \mathrm{O}_{3}$ so the SEM data could be compared to the pXRF data more easily.

The possible raw material sources for the identified petrographic fabrics, and therefore the provenance of the sherds, were interpreted by comparison to geological maps and reports (Force 1991; Lowe 1920; Moore and Bicker, 1969; U.S. Geological Survey 2019). Fossil material of the oyster subfamily Exogyrinae and another unidentifiable type were collected from Josey Creek in the south of the study area (Figure 2). These were crushed and added to studio clay to create experimental briquettes, which were thin sectioned and compared to the temper material in the archaeological ceramics. 


\begin{tabular}{|c|c|c|c|c|c|c|c|c|c|c|c|c|}
\hline Sample & Site & $\begin{array}{l}\text { Macroscopic } \\
\text { Fabric }\end{array}$ & Petrographic Fabric & Type & $\mathrm{CaO}$ & $\mathrm{Fe}_{2} \mathrm{O}_{3}$ & $\mathbf{K}_{2} \mathbf{O}$ & $\mathrm{TiO}_{2}$ & $\mathbf{R b}$ & $\mathrm{Sr}$ & $\mathbf{Z n}$ & $\mathbf{Z r}$ \\
\hline MSC013 & Stark Farm & Recent Shell & Recent Shell-Tempered Fabric & Mississippi Plain & 7.93 & 7.69 & 0.71 & 0.96 & 41 & 237 & 80 & 305 \\
\hline MSC026 & Lyon's Bluff & Recent Shell & Recent Shell-Tempered Fabric & Mississippi Plain & 16.14 & 8.22 & 1.01 & 1.43 & 64 & 420 & 110 & 411 \\
\hline $\mathrm{MSC028}$ & Lyon's Bluff & Recent Shell & Recent Shell-Tempered Fabric & Bell Plain & 34.1 & 5.06 & 0.55 & 1.05 & 39 & 754 & 58 & 235 \\
\hline MSC030 & Lyon's Bluff & Recent Shell & Recent Shell-Tempered Fabric & Mississippi Plain & 24.72 & 4.76 & 1.09 & 1.16 & 64 & 617 & 89 & 205 \\
\hline MSC032 & Lyon's Bluff & Recent Shell & Recent Shell-Tempered Fabric & Mississippi Plain & 16.03 & 6.83 & 0.52 & 1.07 & 48 & 349 & 111 & 305 \\
\hline MSC033 & Lyon's Bluff & Fossil Shell & Recent Shell-Tempered Fabric & Wilson Plain & 14.65 & 6.45 & 1.16 & 1.65 & 70 & 406 & 127 & 381 \\
\hline MSC034 & Lyon's Bluff & Recent Shell & Recent Shell-Tempered Fabric & Bell Plain & 23.93 & 5.58 & 0.94 & 1.43 & 73 & 569 & 167 & 331 \\
\hline MSC036 & Lyon's Bluff & Recent Shell & Recent Shell-Tempered Fabric & Mississippi Plain & 26 & 5.79 & 0.68 & 1.2 & 47 & 445 & 104 & 254 \\
\hline MSC038 & Lyon's Bluff & Recent Shell & Recent Shell-Tempered Fabric & Mississippi Plain & 16.74 & 5.6 & 1.89 & 1.38 & 129 & 402 & 178 & 389 \\
\hline MSC040 & Lyon's Bluff & Recent Shell & Recent Shell-Tempered Fabric & Mississippi Plain & 13.98 & 6.56 & 1.42 & 1.19 & 59 & 384 & 157 & 264 \\
\hline MSC042 & Lyon's Bluff & Recent Shell & Recent Shell-Tempered Fabric & Mississippi Plain & 23.55 & 5.36 & 0.57 & 1.26 & 36 & 531 & 95 & 269 \\
\hline $\mathrm{MSC044}$ & Lyon's Bluff & Recent Shell & Recent Shell-Tempered Fabric & Mississippi Plain & 18.74 & 4.41 & 1.2 & 1.21 & 54 & 351 & 117 & 331 \\
\hline MSC003 & Stark Farm & Recent Shell & Iron-Rich Recent Shell Tempered Fabric & Mississippi Plain & 15.17 & 7.03 & 1.27 & 1.19 & 57 & 338 & 71 & 356 \\
\hline MSC005 & Stark Farm & Recent Shell & Iron-Rich Recent Shell Tempered Fabric & Alabama River Incised & 3.05 & 8.36 & 1.32 & 0.88 & 71 & 189 & 178 & 290 \\
\hline MSC006 & Stark Farm & Recent Shell & Iron-Rich Recent Shell Tempered Fabric & Parkin Punctate & 10.21 & 8.09 & 1.32 & 1.1 & 48 & 254 & 125 & 336 \\
\hline MSC007 & Stark Farm & Recent Shell & Iron-Rich Recent Shell Tempered Fabric & Parkin Punctate & 8.65 & 10.1 & 1.08 & 0.97 & 52 & 242 & 158 & 224 \\
\hline MSC008 & Stark Farm & Recent Shell & Iron-Rich Recent Shell Tempered Fabric & Ridge Plain Applique & 1.52 & 8.47 & 1.02 & 1.06 & 48 & 119 & 105 & 360 \\
\hline MSC009 & Stark Farm & Recent Shell & Iron-Rich Recent Shell Tempered Fabric & Bell Plain & 4.45 & 10.07 & 0.53 & 0.85 & 35 & 140 & 96 & 232 \\
\hline MSC011 & Stark Farm & Recent Shell & Iron-Rich Recent Shell Tempered Fabric & Parkin Punctate & 6.33 & 7.98 & 0.8 & 1 & 37 & 183 & 119 & 411 \\
\hline MSC012 & Stark Farm & Fine Sand & Iron-Rich Recent Shell Tempered Fabric & Ridge Plain & 1.95 & 7.88 & 0.83 & 0.88 & 43 & 202 & 108 & 289 \\
\hline $\mathrm{MSC} 014$ & Stark Farm & Recent Shell & Iron-Rich Recent Shell Tempered Fabric & Mississippi Plain & 11.68 & 9.23 & 0.86 & 0.95 & 60 & 269 & 134 & 295 \\
\hline MSC017 & Stark Farm & Recent Shell & Iron-Rich Recent Shell Tempered Fabric & Alabama River Applique & 9.43 & 11.13 & 1.07 & 1.14 & 54 & 288 & 205 & 270 \\
\hline MSC018 & Stark Farm & Recent Shell & Iron-Rich Recent Shell Tempered Fabric & Parkin Punctate & 4.76 & 9.89 & 1.14 & 0.92 & 60 & 190 & 154 & 274 \\
\hline MSC019 & Stark Farm & Recent Shell & Iron-Rich Recent Shell Tempered Fabric & Parkin Punctate & 5.3 & 9.63 & 1.17 & 0.98 & 57 & 231 & 291 & 265 \\
\hline MSC022 & Stark Farm & Recent Shell & Iron-Rich Recent Shell Tempered Fabric & Bell Plain & 4.67 & 9.71 & 0.72 & 1.02 & 39 & 257 & 112 & 261 \\
\hline $\mathrm{MSC} 023$ & Stark Farm & Recent Shell & Iron-Rich Recent Shell Tempered Fabric & Bell Plain (Notched) & 2.22 & 9.92 & 1.19 & 1.16 & 60 & 139 & 176 & 351 \\
\hline MSC025 & Stark Farm & Recent Shell & Iron-Rich Recent Shell Tempered Fabric & Parkin Punctate & 3.97 & 11.08 & 1.42 & 1.04 & 71 & 185 & 192 & 234 \\
\hline MSC046 & Rolling Hills & Recent Shell & Iron-Rich Recent Shell Tempered Fabric & Mississippi Incised & 1.7 & 7 & 1.31 & 0.85 & 62 & 144 & 180 & 342 \\
\hline MSC047 & Rolling Hills & Recent Shell & Iron-Rich Recent Shell Tempered Fabric & Mississippi Plain & 2.12 & 13.41 & 1.18 & 0.98 & 65 & 231 & 171 & 239 \\
\hline $\mathrm{MSC} 054$ & Rolling Hills & Recent Shell & Iron-Rich Recent Shell Tempered Fabric & Mississippi Plain & 5.38 & 10.05 & 1.1 & 0.86 & 62 & 206 & 137 & 221 \\
\hline MSC057 & Rolling Hills & Fossil Shell & Iron-Rich Recent Shell Tempered Fabric & Wilson Plain & 3.99 & 9.72 & 1.41 & 0.97 & 60 & 189 & 222 & 283 \\
\hline MSC001 & Stark Farm & Fossil Shell & Fossil Shell-Tempered Fabric & Wilson Plain & 9.98 & 11.46 & 0.95 & 1.05 & 50 & 282 & 138 & 231 \\
\hline MSC021 & Stark Farm & Fossil Shell & Fossil Shell-Tempered Fabric & Oktibbeha Plain & 7.57 & 9.38 & 1.77 & 0.97 & 53 & 223 & 182 & 277 \\
\hline MSC029 & Lyon's Bluff & Fossil Shell & Fossil Shell-Tempered Fabric & Wilson Plain & 5.07 & 7.95 & 2.18 & 1.11 & 113 & 209 & 186 & 407 \\
\hline MSC031 & Lyon's Bluff & Fossil Shell & Fossil Shell-Tempered Fabric & Wilson Plain & 12.42 & 5.47 & 1.43 & 1.1 & 52 & 298 & 160 & 344 \\
\hline MSC037 & Lyon's Bluff & Fossil Shell & Fossil Shell-Tempered Fabric & Wilson Plain & 4.9 & 10.59 & 1.15 & 0.88 & 59 & 187 & 206 & 277 \\
\hline MSC039 & Lyon's Bluff & Fossil Shell & Fossil Shell-Tempered Fabric & Oktibbeha Plain & 6.76 & 3.99 & 0.86 & 1.04 & 58 & 203 & 140 & 488 \\
\hline MSC041 & Lyon's Bluff & Fossil Shell & Fossil Shell-Tempered Fabric & Wilson Plain & 21.53 & 9.78 & 1.19 & 1.07 & 47 & 536 & 242 & 172 \\
\hline $\mathrm{MSC} 045$ & Lyon's Bluff & Fossil Shell & Fossil Shell-Tempered Fabric & Oktibbeha Plain & 8.42 & 10.1 & 1.37 & 1.03 & 57 & 353 & 186 & 249 \\
\hline MSC052 & Rolling Hills & Recent Shell & Fossil Shell-Tempered Fabric & Mississippi Incised & 1.46 & 5.83 & 0.73 & 1 & 45 & 94 & 96 & 523 \\
\hline MSC061 & Rolling Hills & Fossil Shell & Fossil Shell-Tempered Fabric & Wilson Plain & 10.05 & 11.55 & 1.14 & 1.14 & 58 & 281 & 229 & 225 \\
\hline
\end{tabular}




\begin{tabular}{|c|c|c|c|c|c|c|c|c|c|c|c|c|}
\hline MSC062 & Rolling Hills & Fossil Shell & Fossil Shell-Tempered Fabric & Wilson Plain & 10.45 & 11.09 & 1.05 & 1.24 & 62 & 294 & 156 & 228 \\
\hline MSC063 & Rolling Hills & Fossil Shell & Fossil Shell-Tempered Fabric & Wilson Plain & 6.65 & 12.13 & 1.3 & 1.23 & 51 & 245 & 190 & 205 \\
\hline MSC002 & Stark Farm & Fossil Shell & Fossil and Recent Shell-Tempered Fabric & Wilson Plain & 16.85 & 10.32 & 0.94 & 1.1 & 41 & 371 & 101 & 226 \\
\hline MSC004 & Stark Farm & Recent Shell & Fossil and Recent Shell-Tempered Fabric & Mississippi Plain & 11.16 & 10.4 & 1.18 & 1 & 52 & 316 & 182 & 247 \\
\hline MSC016 & Stark Farm & Recent Shell & Fossil and Recent Shell-Tempered Fabric & Bell Plain (Notched) & 5.05 & 10.28 & 1.37 & 0.92 & 69 & 227 & 141 & 251 \\
\hline MSC020 & Stark Farm & Fossil Shell & Fossil and Recent Shell-Tempered Fabric & Oktibbeha Plain & 9.26 & 8.9 & 1.53 & 1 & 54 & 250 & 152 & 299 \\
\hline MSC027 & Lyon's Bluff & Fossil Shell & Fossil and Recent Shell-Tempered Fabric & Wilson Plain & 18.33 & 10.46 & 1.21 & 1.24 & 59 & 440 & 151 & 258 \\
\hline MSC035 & Lyon's Bluff & Fossil Shell & Fossil and Recent Shell-Tempered Fabric & Wilson Plain & 15.71 & 5.24 & 1.22 & 1.08 & 101 & 326 & 169 & 256 \\
\hline MSC043 & Lyon's Bluff & Fossil Shell & Fossil and Recent Shell-Tempered Fabric & Wilson Plain & 14.56 & 10.12 & 0.74 & 1.06 & 39 & 444 & 141 & 249 \\
\hline MSC049 & Rolling Hills & Recent Shell & Fossil and Recent Shell-Tempered Fabric & Mississippi Incised & 6.39 & 10.59 & 1.22 & 0.89 & 65 & 243 & 148 & 259 \\
\hline MSC055 & Rolling Hills & Recent Shell & Fossil and Recent Shell-Tempered Fabric & Mississippi Plain & 6.63 & 10.78 & 1.42 & 1.09 & 44 & 281 & 231 & 278 \\
\hline MSC056 & Rolling Hills & Fossil Shell & Fossil and Recent Shell-Tempered Fabric & Wilson Plain & 6.72 & 11.31 & 1.26 & 0.99 & 64 & 264 & 159 & 226 \\
\hline MSC059 & Rolling Hills & Fossil Shell & Fossil and Recent Shell-Tempered Fabric & Wilson Plain & 7.05 & 10.56 & 1.37 & 1.13 & 75 & 251 & 238 & 230 \\
\hline MSC010 & Stark Farm & Recent Shell & Glauconite-Rich Sand and Shell-Tempered Fabric & Barton Incised & 3.91 & 11.71 & 1.97 & 0.78 & 73 & 146 & 146 & 155 \\
\hline MSC048 & Rolling Hills & Recent Shell & Glauconite-Rich Sand and Shell-Tempered Fabric & Mississippi Incised & 4.75 & 10.13 & 1.66 & 0.81 & 78 & 196 & 133 & 209 \\
\hline MSC050 & Rolling Hills & Recent Shell & Glauconite-Rich Sand and Shell-Tempered Fabric & Mississippi Incised & 2.65 & 9.67 & 1.53 & 0.84 & 76 & 153 & 215 & 236 \\
\hline MSC051 & Rolling Hills & Recent Shell & Glauconite-Rich Sand and Shell-Tempered Fabric & Mississippi Plain & 4.86 & 10.15 & 2.03 & 0.92 & 69 & 248 & 157 & 246 \\
\hline MSC053 & Rolling Hills & Recent Shell & Glauconite-Rich Sand and Shell-Tempered Fabric & Mississippi Plain & 3.89 & 13.17 & 2.24 & 0.85 & 100 & 168 & 371 & 181 \\
\hline MSC058 & Rolling Hills & Fossil Shell & Glauconite-Rich Sand and Shell-Tempered Fabric & Wilson Plain & 6.14 & 9.98 & 1.74 & 0.82 & 69 & 213 & 128 & 225 \\
\hline MSC060 & Rolling Hills & Fossil Shell & Glauconite-Rich Sand and Shell-Tempered Fabric & Wilson Plain & 4.99 & 13.44 & 1.85 & 0.79 & 82 & 228 & 176 & 220 \\
\hline MSC024 & Stark Farm & Fine Sand & Micrite, Recent Shell and Grog-Tempered Fabric & Ridge Plain & 22.32 & 7.12 & 1.1 & 0.76 & 50 & 364 & 72 & 229 \\
\hline MSC015 & Stark Farm & Recent Shell & Shell Tempered Clay Pellet Fabric & Alabama River Incised & 1.9 & 8.37 & 1.21 & 0.88 & 75 & 135 & 106 & 409 \\
\hline
\end{tabular}

Table 1. Details of the 63 ceramic sherds selected from Stark Farm, Lyon's Bluff, and Rolling Hills, including macroscopic classification supplied by donating institutions, as well as the petrographic fabric classification and geochemical characterization of the present study. Four major oxides given as percentage weight oxides and four minor elements given as elemental parts per million. Elemental data quality assessment outlined in Appendix 3. 


\section{Results}

Examination of the fabric of the 63 selected sherds at low magnification and comparison with their assigned macroscopic fabric classification revealed some points of agreement but also several mismatches. Most samples classified as Recent Shell had platy calcareous inclusions that were somewhat aligned to the margins of the vessels (Figure 3A), whereas the Fossil Shell sherds contained more equant, blocky carbonate grains that have the appearance of crushed limestone (Figure 3B). Despite this general correspondence, several examples of Recent Shell sherds with occasional blocky limestone inclusions were encountered as well as Fossil Shell sherds with shiny platy grains. One reason for this misidentification might be the flakey mica-like inclusions within many of the ceramics. These are difficult to distinguish macroscopically, and although they could have come from the shiny inner layer of either the nacreous Unionid freshwater mussel shells or the porcelaneous Exogyrid and Pycnodont fossil oyster shells, they are commonly identified as a defining characteristic of the recent mussel shell temper (Barthelat 2010; Sun and Bhushan 2012; Yao et al. 2013). The sherds identified as Fine Sand had little if any visible shell, but instead contained sand-sized silicate mineral inclusions, which appeared to be rich in quartz. Many of the shell tempered sherds of both types also contained quartz sand grains, thus also blurring the distinction of the Fine Sand category.

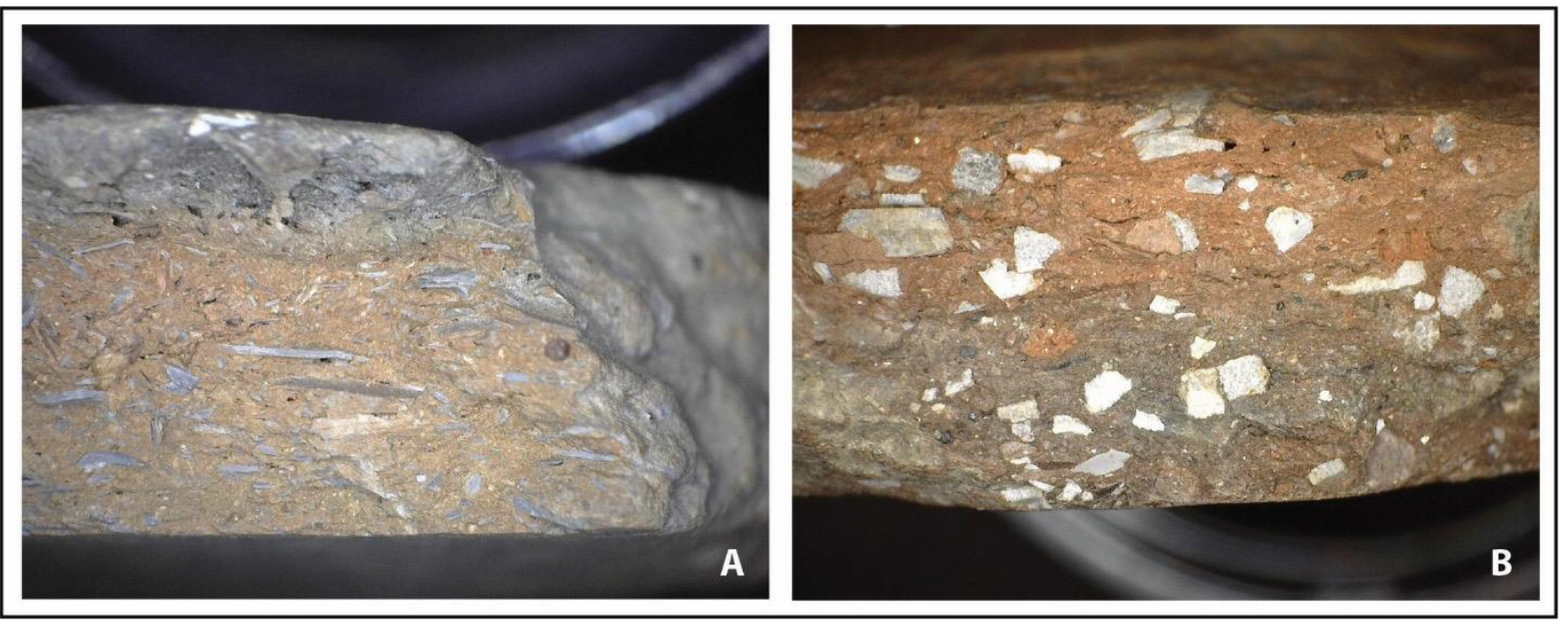

Figure 3. Macroscopic difference between recent shell temper (A) and fossil shell temper (B). Image width $\mathrm{A}=25 \mathrm{~mm}, \mathrm{~B}=12 \mathrm{~mm}$.

By analyzing in more detail the composition of the 63 sherds in thin section under the petrographic microscope, we subdivided them into seven distinct fabrics or 'recipes' based on their raw materials and paste preparation technology (Table 1; Figure 4). These reflect the broad macroscopic categories above, but also record additional compositional and technological variability. A scatterplot of principal components 1 and 2 from the PCA of the eight elements measured with pXRF, which explained $63 \%$ of the total variance in the dataset, reveals a large cloud with several outliers (Figure 5A, B, F). Geochemical patterning can be discerned within the plot by labelling the samples according to their macroscopic temper classification and petrographic fabric assignment. This indicates that the dominant Recent Shell and Fossil Shell sherds overlap geochemically, but also 
both contain significant compositional variability (Figure 5A). Highlighting the sherds' petrographic fabric assignment (Figure 5B) suggests that this is due to the existence of several additional and as yet undetected recipes that can be defined by the concentrations of the elements $\mathrm{Fe}_{2} \mathrm{O}_{3}, \mathrm{Rb}$, $\mathrm{Sr}$, and $\mathrm{TiO}_{2}$ (Figure 5C-E, Table 1), as well as microscopically.

The Recent Shell-Tempered Fabric and the Iron-rich Recent Shell Tempered Fabric are characterized in thin section by the presence of shell temper in a moderately calcareous clay matrix (Figure 4A-B). The former is defined by large, elongate shell inclusions and occurs almost exclusively at Lyon's Bluff in the analyzed samples (Figure 4A). The latter contains finer, less frequent shell fragments plus frequent opaque ferruginous inclusions (Figure 4B) and is found mostly at Stark Farm. In both cases, the shell inclusions have a gray-brown color and an elongate, or platy shape. They appear to be composed of layers of sheet nacre (Figure 4A-B; Figure 6A-B, C), which is characteristic of freshwater mussels (Yao et al. 2013). This includes members of the family Unionidae, which Steponaitis (1983, p. 20) suggested as the probable shell added to ceramics in a contemporaneous assemblage from the Moundville site. The high abundance of shell in the ceramics supports the idea that the recent shell was added deliberately as temper rather than unintentionally as part of a naturally shell clay deposit. The angular outlines of the fragments are indicative of crushing prior to addition. The platy structure of the shell may suggest that the material was intentionally heated or calcined before use (Feathers 1989), a practice that has been reported ethnographically (e.g. the Pamunkey of Virginia, USA) and serves to both aid the crushing process and reduce damage to the ceramics due to the alteration of the aragonitic shells during firing (Speck 1928). Some fragments contain micritic calcite crystals along their edges and fractures (Figure 4AB), which may support this idea (Collins 2012; Maritan et al. 2007).

The two related petrographic fabrics can be distinguished from each other in thin section based upon a higher abundance of opaque inclusions in the Iron-rich Recent Shell Tempered Fabric, which had a high iron content when analyzed by SEM-EDS (Table 2). Not surprisingly sherds belonging to this fabric have a greater bulk concentration of $\mathrm{Fe}_{2} \mathrm{O}_{3}$ (Figure 5C; Table 1). Samples classified within the Recent Shell-Tempered Fabric have higher relative $\mathrm{CaO}$ and $\mathrm{Sr}$ (Table 1; Figure 5D) due to the greater proportion of carbonate shell (Figure 5E; Table 1). Ceramics of both fabrics contain inclusions of heavy minerals such as ilmenite and rutile, which were likely to have been present in the base clay to which temper was added (Figure 6A; Table 2).

The Fossil Shell-Tempered Fabric is characterized by the presence of fossil shell inclusions in a slightly calcareous clay matrix (Figure 4C). This fabric is present among the sherds collected from all three sites. The majority of fossil shell inclusions had a more blocky and less platy shape compared to the recent shell. Their microstructure matched that of the thin sections of experimental briquettes tempered with Exogyrinae fossils and the previously unidentified fossil shell specimens, which could be ascribed to the subfamily Pycnodonteinae. Shell of the Exogyrinae exhibits a foliated or lamellar microstructure composed of calcite with chalky lenses, whereas Pycnodonteinae shell has a distinctive vesicular or 'honeycomb' microstructure that alternates with foliated lamellae (Jaitley et al. 2014; Stenzel 1971) (Figure 4D). Sherds of the Fossil Shell-Tempered Fabric have a similar bulk geochemical composition to that of the Iron-rich Recent Shell-Tempered Fabric (Figure 5B) in that they have relatively high $\mathrm{Fe}_{2} \mathrm{O}_{3}$ and low $\mathrm{K}_{2} \mathrm{O}, \mathrm{Rb}, \mathrm{Sr}$, and $\mathrm{TiO}_{2}($ Figure $4 \mathrm{C}$ $\mathrm{E}$; Table 1). Unexpectedly, eleven sherds related petrographically and chemically to the above fabric also contain variable amounts of recent mussel shell of the family Unionidae (Figure 4E), 
that appear to have been a deliberate addition. Specimens belonging to this Fossil and Recent Shell-Tempered Fabric are present at all three sites. The coexistence of the shell types was not detected macroscopically in the initial temper type classification of the 63 sherds in this assemblage and has not been reported in other studies in the region.

Seven sherds, all but one from Rolling Hills, were characterized in thin section by recent shell and/or fossil shell temper, plus rounded sand-sized grains of quartz and glauconite in a calcareous clay matrix (Figure 4F; 6F). Whilst quartz is present in sherds belonging to the above fabrics, it tends to be finer and is not accompanied by glauconite. The sand is likely to have been an additional temper ingredient in the pottery classified as the Glauconite-Rich Sand and Shell-Tempered Fabric, which was not picked up by the macroscopic classification. The seven sherds are geochemically as well as petrographically distinctive in terms of their high levels of $\mathrm{K}_{2} \mathrm{O}$ and $\mathrm{Fe}_{2} \mathrm{O}_{3}(\mathrm{Figure}$ $5 \mathrm{C}, \mathrm{E}$ ), which are likely to be related to the presence of glauconite (Table 2), plus their low $\mathrm{TiO}_{2}$ (Figure 5E).

The last two sherds in this study have petrographic fabric recipes that are rare in the analyzed assemblage. The single Micrite, Recent Shell, and Grog-Tempered Fabric sherd, which comes from Stark Farm, is tempered with freshwater mussel shell, but differs from the other two related fabrics in that it also contains micritic limestone inclusions and crushed pottery temper, or 'grog' (Figure 4H). Another sherd from Stark Farm represents the Shell-Tempered Clay Pellet Fabric (Figure 4G). This contains small amounts of recent Unionidae shell temper in a calcareous clay matrix, but it set apart by the presence of large dark red clay pellets, which appear to be a natural occurrence.

A comparison between the seven petrographic recipes and the type-variety classification of the analyzed sherds (Table 1) reveals some minor correspondence. For example, samples belonging to the Recent Shell-Tempered Fabric were mostly classified as Mississippi Plain, those within the Fossil Shell-Tempered Fabric and to an extent the Fossil and Recent Shell-Tempered Fabric are mostly Wilson Plain, and finally the Parkin Punctate sherds were only present as the Iron-Rich Recent Shell Tempered Fabric. Unfortunately, it is not possible to determine the relationship between the seven petrographic fabrics and vessel shape and probable function, given the non-diagnostic nature of the small sherds. 


\begin{tabular}{|c|c|c|c|c|c|c|c|c|c|c|c|c|c|c|c|c|c|}
\hline MSC042 & & $\mathrm{SiO}_{2}$ & $\mathrm{Al}_{2} \mathrm{O}_{3}$ & $\mathrm{Fe}_{2} \mathrm{O}_{3}$ & $\mathrm{CaO}$ & $\mathbf{K}_{2} \mathbf{O}$ & $\mathrm{TiO}_{2}$ & MnO & $\mathbf{P}_{2} \mathrm{O}_{5}$ & $\mathrm{SO}_{3}$ & $\mathrm{Sc}_{2} \mathrm{O}_{3}$ & $\mathrm{~V}_{2} \mathrm{O}_{5}$ & $\mathrm{ZrO}_{2}$ & $\mathrm{Nb}_{2} \mathrm{O}_{5}$ & $\mathrm{HfO}_{2}$ & Total & $\begin{array}{l}\text { Analytical } \\
\text { Total }\end{array}$ \\
\hline 1 & Clay matrix & 44.02 & 25.34 & 10.50 & 16.59 & 1.27 & 1.09 & & 0.41 & & 0.19 & & & & & 100.00 & 79.00 \\
\hline 2 & Clay matrix & 61.51 & 16.62 & 5.45 & 9.74 & 0.71 & 0.91 & & & 4.67 & & & & & & 100.00 & 86.33 \\
\hline 6 & Clay matrix & 51.34 & 29.58 & 7.87 & 8.23 & 1.29 & 0.98 & & & & & & & & & 100.00 & 83.39 \\
\hline 3 & Recent shell & 0.62 & 0.41 & 0.41 & 98.59 & & & & & & & & & & & 100.00 & 54.05 \\
\hline 4 & Recent shell & 0.63 & 0.41 & & 98.21 & & & 0.26 & & 0.50 & & & & & & 100.00 & 55.24 \\
\hline 7 & Recent shell & 0.50 & 0.41 & & 98.50 & & & 0.28 & & 0.32 & & & & & & 100.00 & 55.44 \\
\hline 8 & Recent shell & 0.45 & 0.29 & & 99.25 & & & & & & & & & & & 100.00 & 54.47 \\
\hline 5 & $\begin{array}{l}\text { Heavy min- } \\
\text { eral }\end{array}$ & 2.95 & 1.24 & 1.19 & 1.18 & 0.07 & 91.60 & & & & & 0.84 & & 1.05 & & 100.00 & 102.54 \\
\hline \multicolumn{18}{|c|}{\begin{tabular}{|l|l} 
MSC012 & \\
\end{tabular}} \\
\hline 9 & Clay matrix & 50.72 & 33.58 & 8.38 & 3.14 & 1.44 & 0.89 & & 0.98 & & & & & & & 100.00 & 81.76 \\
\hline 10 & Clay matrix & 51.43 & 33.96 & 7.25 & 2.65 & 2.17 & 1.34 & & 0.97 & & & & & & & 100.00 & 77.67 \\
\hline 13 & Clay matrix & 35.05 & 24.37 & 36.62 & 3.48 & 0.67 & 0.68 & & 2.10 & & & & & & & 100.00 & 71.93 \\
\hline 14 & Clay matrix & 51.56 & 32.85 & 8.52 & 3.27 & 1.52 & 0.90 & & 1.07 & & & & & & & 100.00 & 71.99 \\
\hline 11 & $\begin{array}{l}\text { Iron-rich in- } \\
\text { clusion }\end{array}$ & 5.20 & 4.26 & 96.98 & 1.43 & & & & 1.84 & & & & & & & 100.00 & 73.42 \\
\hline 15 & $\begin{array}{l}\text { Iron-rich in- } \\
\text { clusion }\end{array}$ & 10.52 & 13.98 & 76.79 & 2.23 & 0.48 & 0.28 & & 3.41 & & & & & & & 100.00 & 78.56 \\
\hline 12 & $\begin{array}{l}\text { Heavy min- } \\
\text { eral }\end{array}$ & 2.52 & 3.28 & 4.89 & 1.15 & 0.12 & 86.27 & & 1.21 & & & 1.05 & & & & 100.00 & 88.26 \\
\hline 16 & $\begin{array}{l}\text { Heavy min- } \\
\text { eral }\end{array}$ & 30.71 & & 0.23 & 0.24 & & & & & & & & 65.39 & 2.10 & 1.35 & 100.00 & 90.10 \\
\hline \multicolumn{18}{|l|}{ MSC058 } \\
\hline 17 & Clay matrix & 49.91 & 29.45 & 11.58 & 3.36 & 1.72 & 0.68 & & 2.12 & & & & & & & 100.00 & 85.80 \\
\hline 19 & Clay matrix & 52.29 & 31.52 & 9.08 & 2.38 & 1.83 & 0.66 & & 1.00 & & & & & & & 100.00 & 83.86 \\
\hline 20 & Clay matrix & 54.20 & 30.40 & 8.48 & 2.02 & 1.94 & 0.90 & & 0.98 & & & & & & & 100.00 & 80.71 \\
\hline 18 & Glauconite & 52.51 & 17.65 & 20.31 & 1.32 & 5.84 & & & 0.51 & & & & & & & 100.00 & 91.35 \\
\hline 21 & Glauconite & 51.37 & 15.53 & 24.02 & 1.79 & 5.02 & & & 0.91 & & & & & & & 100.00 & 87.85 \\
\hline
\end{tabular}

Table 2. Geochemical characterization via SEM-EDS of selected features of representative sherds from the Recent Shell-Tempered Fabric (MSC042), Iron-Rich Recent Shell Tempered Fabric (MSC012), and Glauconite-Rich Sand and Shell-Tempered Fabric (MSC058). See Figure 6 for the location of the numbered analyses. Data presented as percentage weight oxides. Elemental data quality assessment outlined in Appendix 3. 


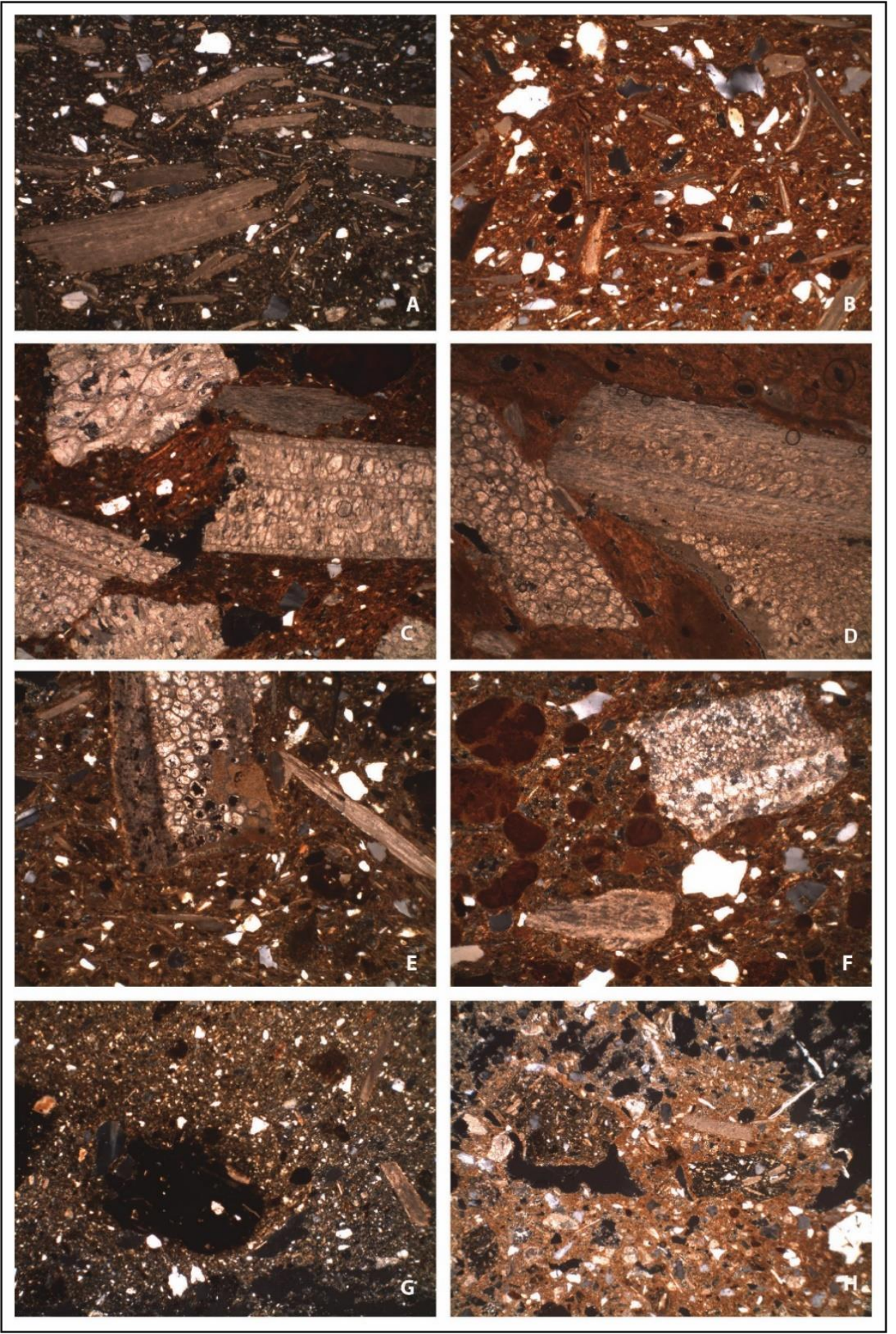

Figure 4. Thin section photomicrographs of petrographic fabrics or recipes detected among the 63 Chickasaw sherds from Stark Farm, Lyon's Bluff, and Rolling Hills analyzed in this study, plus experimental shell-tempered briquettes. A. Recent Shell-Tempered Fabric; B. Iron-Rich Recent Shell Tempered Fabric; C. Fossil Shell-Tempered Fabric; D. Experimental briquette tempered with fossil Pycnodonteinae shell; E. Fossil and Recent Shell-Tempered Fabric; F. Glauconite-Rich Sand and Shell-Tempered Fabric; G. Shell Tempered Clay Pellet Fabric; H. Micrite, Recent Shell, and Grog-Tempered Fabric. All images taken in crossed polars. Image width $=3.0 \mathrm{~mm}$. 

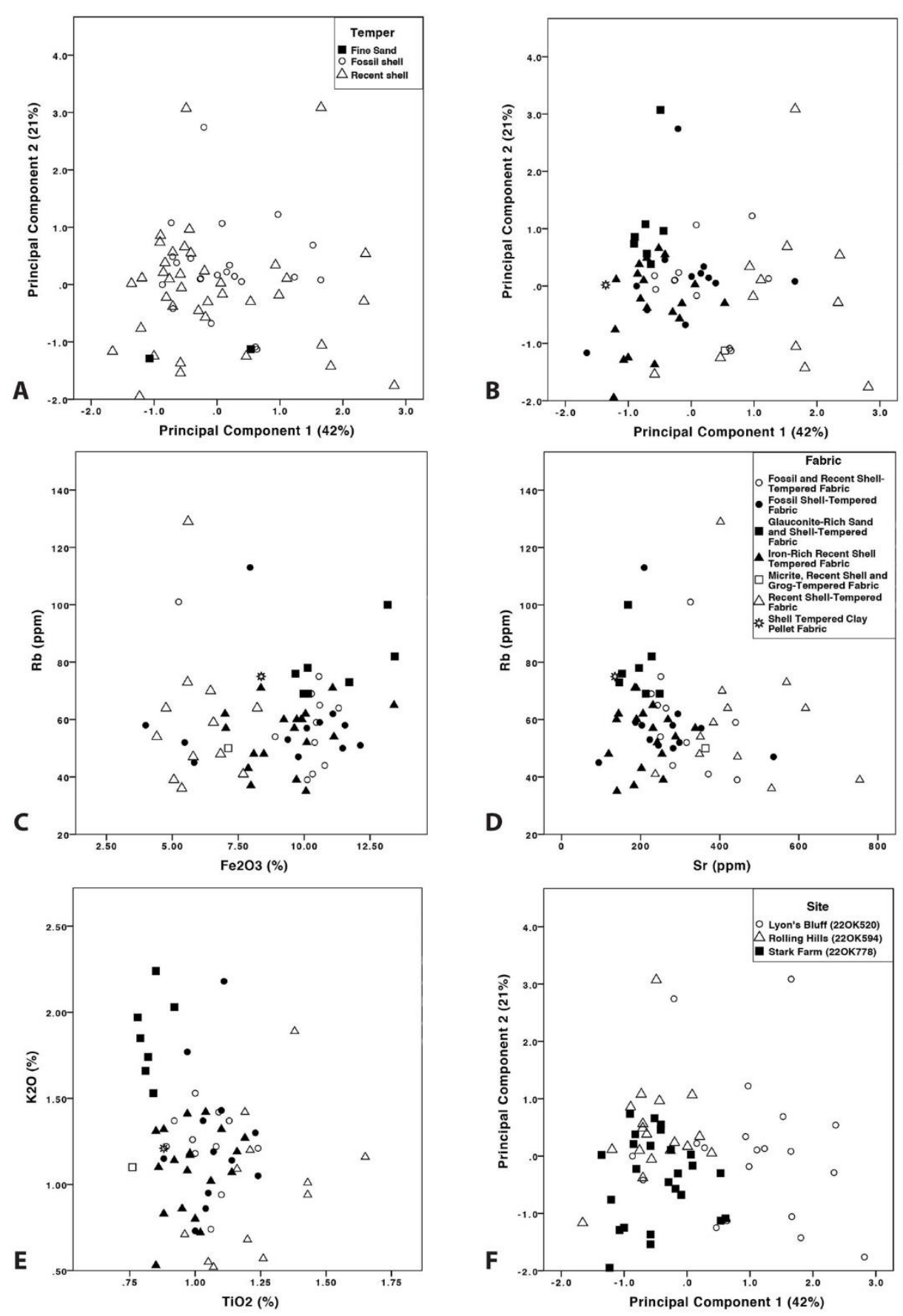

Figure 5. Compositional classification of 63 Chickasaw sherds from Stark Farm, Lyon's Bluff, and Rolling Hills based on geochemical data from eight major, minor and trace elements collected via pXRF. A. Scatterplot of principal components 1 and 2 with samples labelled according to macroscopic temper type. B. Scatterplot of principal components 1 and 2 with samples labelled according to petrographic fabric. C. Scatterplot of $\mathrm{Fe}_{2} \mathrm{O}_{3}$ and $\mathrm{Rb}$ with samples labelled according to petrographic fabric. D. Scatterplot of $\mathrm{Sr}$ and $\mathrm{Rb}$ with samples labelled according to petrographic fabric. E. Scatterplot of $\mathrm{TiO}_{2}$ and $\mathrm{K}_{2} \mathrm{O}$ with samples labelled according to petrographic fabric. $\mathrm{F}$. Scatterplot of principal components 1 and 2 with samples labelled according to site. 

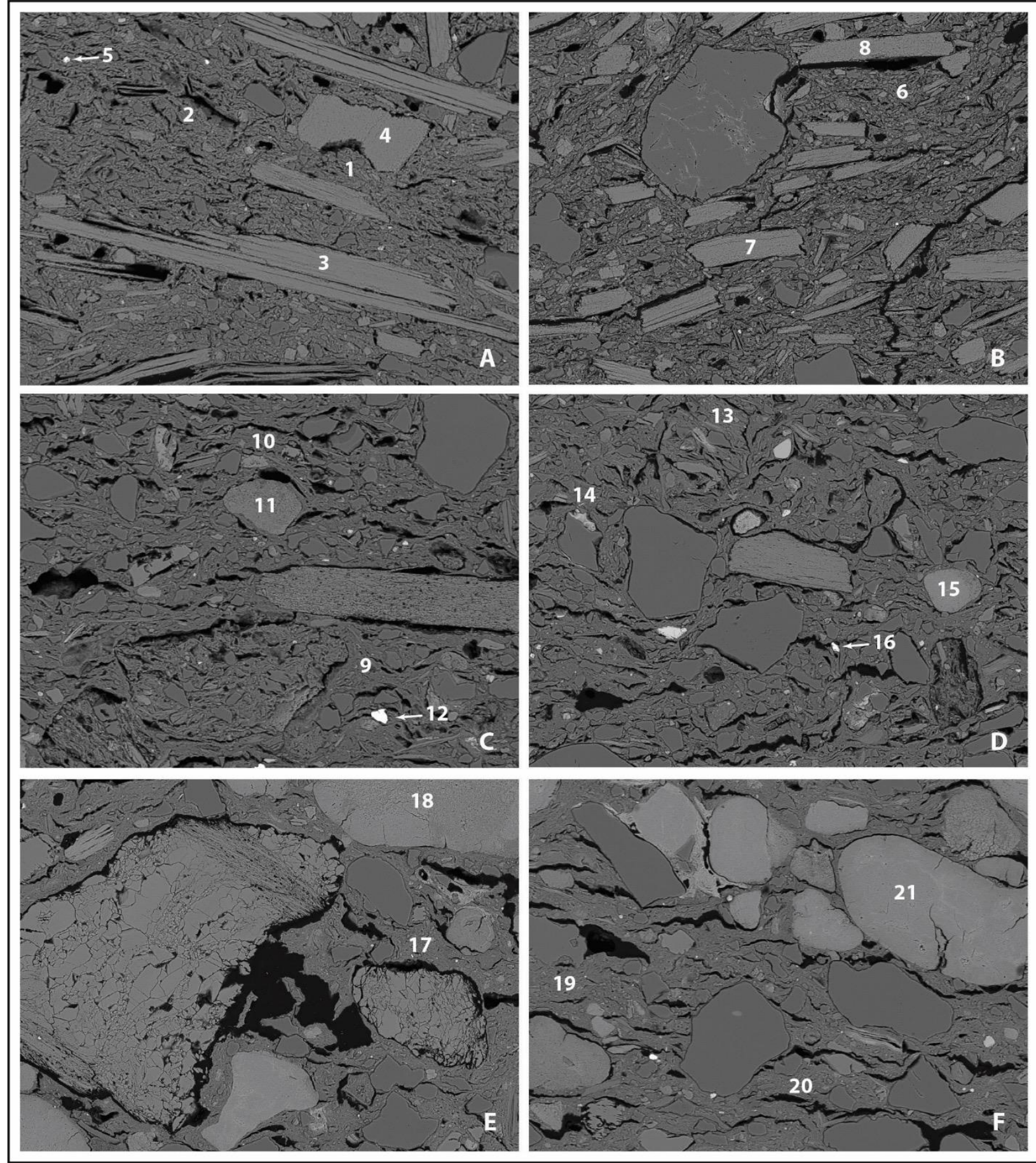

Figure 6. Back-scattered scanning electron micrographs of representative sherds from the Recent Shell-Tempered Fabric (A and B - sample MSC042), Iron-Rich Recent Shell Tempered Fabric (C and D - sample MSC012), and Glauconite-Rich Sand and Shell-Tempered Fabric (E and F MSC058). See Table 2 for the chemical composition of the numbered features. Image width $=800$ microns. 


\section{Discussion and Conclusions}

A broad tripartite subdivision appears to exist within the analyzed ceramic assemblage in hand specimen between Chickasaw ceramics with elongate platy shell material, those with more equant, blocky carbonate grains, and others that appear to lack shell, but contain quartzose sand (Figure 3). However, more detailed examination of the sherds in thin section under the polarizing light microscope reveals that this macroscopic classification, which is widely applied in studies of Mississippian and post-contact Chickasaw sherds (e.g. Rafferty 1995; Smith 2017), is not clear-cut and significant additional compositional and technological variability exists (Figure 4). Platy inclusions that are confirmed to have derived from recent mussel shell occur in over half of the 63 sherds from the three sites and appear to represent temper. Nevertheless, these samples can be further subdivided in thin section based upon whether or not they contain abundant iron-rich inclusions, micritic limestone grains, or grog temper.

\subsection{Macroscopic Investigation}

A significant proportion of the analyzed sherds, many of which were classified macroscopically as the Fossil Shell type, do indeed contain shell that matches fossil material belonging to the taxa Pycnodonteinae and Exogyrinae. As with the Recent Shell tempered sherds, these can be further subdivided based upon the presence of additional inclusion types. Several also contain recent mussel shell temper, while others feature rounded glauconite sand grains, with or without recent shell. Clearly, the use of fossil and recent shell temper for the production of Chickasaw ceramics was not always mutually exclusive and care should therefore be taken when attempting to subdivide them macroscopically on this basis. While the use of fossil shell appears to be intentional in the Fossil Shell-Tempered Fabric, some sherds belonging to the Fossil and Recent Shell-Tempered Fabric contain only rare fossil fragments. The two 'Fine Sand' sherds were both found to contain shell in thin section (Table 1), with one of them also being made with the addition of grog temper. Quartz sand and silt is in fact present in all the analyzed sherds regardless of their macroscopic classification and it is therefore not a reliable criterion for subdividing them.

As in the re-investigation of other long-standing macroscopic paste classification systems of native ceramics, such as the split between Tizon Brown Ware and Lower Colorado Buff Ware of San Diego County, Southern California (Quinn 2013; Quinn and Burton 2015), the greater resolution provided by thin section petrography has revealed the presence of multiple additional clay paste recipes that can be confirmed by aspects of the geochemistry of the sherds (Figure 5; Table 1). Whilst this throws into doubt the applicability of the pre-existing types and their interpretative value, it also represents an opportunity to shed new light on the nature of Chickasaw pottery production and distribution. 


\subsection{Clay Paste Recipes}

The various clay paste recipes or fabrics defined in this study are likely to represent conscious decisions by Chickasaw potters to utilize specific raw material sources and combine them in a particular fashion. These choices will have been influenced by one or a combination of factors including: the availability of raw materials, their functional properties both during and after manufacture, and the potters' craft traditions and individual choices. The following discussion addresses these influences and considers their implications for our knowledge of the manufacturing technology, origins, and movement of Chickasaw ceramics, and thus, the activities of the people that made them, used them, and left them behind.

By examining the distribution of the seven pottery recipes between the three sites (Table 1; Figure 5) and comparing their interpreted raw materials to the local geology (Figure 2), it is possible to shed light on their likely production locations. Certain fabrics are more or less restricted to a single site in the dataset, for example all but one of the Recent Shell-Tempered Fabric samples come from Lyon's Bluff and the majority of the Iron-Rich Recent Shell Tempered Fabric sherds originate from Stark Farm. This may suggest that ceramics belonging to the two related recipes were produced at or close to these respective sites, which are separated by $14 \mathrm{~km}$ and lie on geologically different strata. The recent Unionidae mussel shell could have been collected from the Tombigbee River and its tributaries and possible candidates for the base clay include the Demopolis Chalk Formation at Lyon's Bluff and the Prairie Bluff Chalk Formation at Stark Farm (Figure 2), both of which contain calcareous clay and chalk (Moore and Bicker 1969). It is not possible to determine without fieldwork whether the Prairie Bluff Chalk Formation contains a high proportion of iron grains as per the Iron-Rich Recent Shell Tempered Fabric, however the Demopolis Chalk Formation is described as having fewer impurities (Moore and Bicker, 1969).

Six out of the seven Glauconite-Rich Sand and Shell-Tempered Fabric sherds originate from Rolling Hills. This may suggest that ceramics of this fabric were also locally produced at this site. The Prairie Bluff Chalk Formation, which underlies the site, is not described as being glauconiterich, however, the Ripley and Clayton Formations, which are each located a few kilometers from Rolling Hills (Figure 2) are composed, in part, of fine glauconitic sand and glauconitic sandy clay (Moore and Bicker 1969), which could have been used for the production of these ceramics. In provenance studies of archaeological ceramics, it is usually assumed that pottery production took place at or close to the utilized sources of raw materials (e.g. Arnold, 1985, p. 32-60; Quinn 2013, p. 119). However, exceptions to this rule are known to have existed in some Native North American cultures (e.g. Heizer and Treganza, 1944, p. 334; Rogers, 1936, p. 4) and it is important to bear in mind that pre- and early-contact period people could have transported small amounts of clay for production elsewhere.

Other recipes, such as the Fossil Shell-Tempered Fabric and the Fossil and Recent Shell-Tempered Fabric are present at all three sites in nearly equal proportions. The fossil shell temper is likely to have derived from either the Cretaceous Selma Chalk Formation Group or the Paleogene Midway Group. Fossil material comparable to the shell within the ceramics was collected from the Prairie Bluff Formation of the former and the nearby Clayton Formation of the latter at a tributary of Josey Creek, close to Stark Farm and Rolling Hills (Figure 2). Nevertheless, both geological units have an extensive distribution in the study area, and fossil shell is known to occur naturally in soil across 
the Blackland Prairie (Ethridge 2010, p.74-75). With this in mind, the ceramics of this fabric could perhaps represent local versions of a single recipe. On the other hand, their geochemical homogeneity (Figure 5B) might tentatively suggest that they came from a single source and were transported via migration, trade, or other interaction. The Chickasaw are thought to have been sedentary (Ethridge 2009, p. 6; Johnson 2000, p. 91) and did not migrate seasonally taking ceramics with them as some other pre-contact North American pottery-making groups, such as the Kumeyaay of San Diego County, California (Quinn and Burton 2015) and the Numa of the southwestern Great Basin (Eerkens, Neff, and Glascock 2001). Nevertheless, inhabitants of different villages interacted with one another and pottery could have played an important role in this process. While Mississippian chiefdoms were thought to have been mostly economically self-sufficient they may have obtained certain prestige goods, like salt, via complex trade and exchange systems with sedentary polities, such as the Naguatex (Hudson 2018, p. 372). It is therefore possible that trade of pottery took place during the Mississippian and post-contact periods, either as a commodity or a container for other goods. Ceramics may have also changed hands as part of gift exchange tied to social processes such as ceremonies or feasts, diplomatic meetings, or marriage (Ethridge 2010).It appears, therefore, that each of the three studied sites contain pottery sherds belonging to a dominant locally produced fabric, but could also feature smaller amounts of material that may have been produced elsewhere. This pattern is informative in terms of the nature of both pottery production and distribution in the region in the past. The presence of broadly local fabrics at each settlement, suggests that ceramics were produced and used on site by their Chickasaw inhabitants. While tempering with fossil shell appears to be specific to the Blackland Prairie region, there existed a broad tradition of recent shell tempering, which was carried out at several different locations using locally available clay. This is in keeping with research on contemporaneous shell-tempered ceramics from the wider American Southeast, ranging as far as the Oneota of Iowa and Wisconsin (Roper 2011) and the Caddo of Oklahoma (Perttula et al. 2012). Potters at the three sites appear to have shared knowledge and were connected culturally in terms of their craft practices.

\subsection{Technological Choice}

It is interesting to speculate about the reasons behind the widespread use of shell, given that other material would also have been available to the Chickasaw potters of the three sites. Sand, for example, can often be used without significant preparation. Crushed shell may represent a suitable material with which to temper utilitarian pots due to several key functional properties. Million (1975, p. 218-219) has suggested that the addition of shell improves the workability of excessively plastic clay, without compromising the ability of the paste to deform without fracturing. The platy shape of shell fragments and other similar-shaped inclusions, such as phyllite, is also better at preventing crack propagation than other more equant inclusions thus improving the toughness of ceramics. Another important property of shell tempering in ceramics is the thermal expansion coefficient of heated shell. Stresses can build up in cooking pots during use if there are large differences in rate and degree of expansion of its various inclusions and clay matrix (Muller 2017). Experiments by Hoard et al. (1995), Rye (1976), and Steponaitis (1983) indicate that the expansion of calcite and aragonite is close to that of fired clay, which reduces the degree of thermal shock that cooking pots are subjected too. One drawback of using shell and other calcareous material as temper is the potential breakdown during and after firing. This process, which is well known (Rice 1987 , p. 81), takes place at c. $750^{\circ} \mathrm{C}$ during firing and can affect the integrity of the object upon cooling as the altered calcite absorbs moisture and expands. Nevertheless, cooking pots are not 
normally subjected to such high temperatures during use (Muller 2017) and they need not be fired to the point of the dissociation of calcite to render them functional (Picon 1995). Chickasaw potters may have been aware of one or more of the above benefits of tempering their pots with shell and this knowledge could have been shared between the inhabitants of the different settlements, as well as further afar.

\subsection{Conclusions}

The unexpected overlap between the Recent Shell, Fossil Shell, and Fine Sand macroscopic categories of Chickasaw ceramics that has been highlighted in this study has important implications for the use of these as a relative dating tool in the region. While the it has not been possible here to comment on the temporal distribution of the three types, the more complicated picture revealed by the scientific analysis and the potential for misidentification suggests that further research is needed before they can be used to assign sites to the Mississippian, early contact, and later postcontact periods. To do this, thin section petrography should be applied to diagnostic sherds from stratified and well dated sites in order to further investigate the compositional categories recorded in this study, their correlation with decorative attributes, and other macroscopic characteristics, as well as their chronological ranges. Attempts should also be made to detect macroscopically some of the additional paste recipes reported in thin section, such as the Glauconite-Rich Sand and ShellTempered Fabric. In this way, it will be possible to examine in more detail the nature of the proposed technological shift in ceramic technology and its possible meaning in terms of the movement of the Chickasaw people through the Blackland Prairie and their interactions with each other and Europeans.

\section{Declarations of interest}

None.

\section{Acknowledgements}

This research presented in this paper was undertaken as part of the MSc in Archaeological Science: Technology and Materials at University College London, Institute of Archaeology. The authors are grateful to Dr. Charles Cobb, who provided support during the initial research set up. Access to the Stark Farm ceramic assemblage was facilitated by Dr. Tony Boudreaux of the Center for Archaeological Research, University of Mississippi, and the Lyon's Bluff and Rolling Hills ceramics were supplied by Dr. Evan Peacock and Dr. Jeffrey Alvey of the Cobb Institute of Archaeology, Mississippi State University. Dr. Brad Lieb of the Chickasaw nation kindly collected the comparative shell material. The authors would also like to thank Allison Smith, whose master's thesis research and personal communication were extremely beneficial for understanding the typological ceramic classifications. This paper was improved by the comments of two anonymous reviewers and Chris O. Hunt, co-editor of The Journal of Archaeological Science: Reports. All scientific preparations analyzed in this study are stored at the Florida Museum of Natural History and can be accessed for comparative purposes with prior arrangement.

This research did not receive any specific grant from funding agencies in the public, commercial, or not-for-profit sectors. 


\section{References}

Arnold, D.E., 1985. Ceramic Theory and Cultural Process. Cambridge University Press, Cambridge.

Atkinson, J. R., 1987. Historic Chickasaw Cultural Material: A More Comprehensive Identification. Mississippi Archaeology, 22(2), 32-62.

Barthelat, F., 2010. Nacre from mollusk shells: a model for high-performance structural materials. Bioinspiration and Biomimetics, 5(3), 1-8.

Blitz, J. H., 1993. Ancient Chiefdoms of the Tombigbee. Tuscaloosa: University of Alabama Press.

Burton, M., Quinn, P. S., Tamberino, A. and Levy, T. 2019. Ceramic composition at Chalcolithic Shiqmim, northern Negev desert, Israel: Investigating technology and provenance using thin section petrography, instrumental geochemistry, and calcareous nannofossils. Levant, 50: 237-257.

Cobb, C., Legg, J., Wescott, K., Lieb, B., Sorresso, D., Edwards, W. and Hall, K., 2016. Results of Test Excavations at Stark Farm (220k778): 2015 Season, Unpublished report. Report submitted to the Chickasaw Nation. Funding provided by the Chickasaw Nation Survey Grant.

Collins, J. D., 2012. Assessing mussel shell diagenesis in the modern vadose zone at Lyon's Bluff (22OK520), Northeast Mississippi. Journal of Archaeological Science, 39(12), 3694-3705.

Day, P.M., Quinn, P.S., Rutter, J.B., Kilikoglou, V., 2011. A world of goods: transport jars and commodity exchange at the late bronze age harbor of Kommos, Crete. Hesperia, 80(4), 511558.

Eerkens, J. W., Neff, H. and Glascock, M. 2002. Ceramic Production among Small-scale and Mobile Hunters and Gatherers: A Case Study from the Southwestern Great Basin. Journal of Anthropological Archaeology, 2, 200-229.

Ethridge, R., 2009. Introduction: Mapping the Mississippian Shatter Zone. In: Ethridge, R. and Shuck-Hall, S. (eds.) Mapping the Mississippian Shatter Zone: The Colonial Indian Slave Trade and Regional Instability in the American South. Lincoln: University of Nebraska Press, 1-63.

Ethridge, R., 2010. From Chicaza to Chickasaw: The European Invasion and the Transformation of the Mississippian World, 1540-1715. Chapel Hill: University of North Carolina Press.

Feathers, J. K., 1989. Effects of temper on strength of ceramics: response to Bronitsky and Hammer. American Antiquity, 54, 579-588.

Force, E.R., 1991. Geology of titanium-mineral deposits. Geological Society of America Special Paper, 259, 3-112.

Heizer, R.F. and Treganza, A.E. 1972. Mines and Quarries of the Indians of California. Ballena 
Press, Ramona, California.

Hogue, S. H., 2000. Burial Practices, Mortality, and Diet in East-Central Mississippi: A Case Study From Oktibbeha County. Southeastern Archaeology, 19, 63-81.

Hudson, C., 2018. Knights of Spain, Warriors of the Sun: Hernando de Soto and the South's Ancient Chiefdoms. Athens: University of Georgia Press.

Jaitly, A., Mishra, S. and Sen, S., 2014. Shell microstructure of late Cretaceous (Maastrichtian) oysters from Ariyalur, Tamil Nadu. Journal of the Geological Society of India, 84(1), 41-54.

Johnson, J.K., 2000. The Chickasaws. In: McEwan, B.G. (ed.) Indians of the Greater Southeast: Historical Archaeology and Ethnohistory. Gainesville: University Press of Florida.

Johnson, J., O'Hear, J., Ethridge, R., Lieb, B., Scott, S. and Jackson, H. E., 2008. Measuring Chickasaw Adaptation on the Western Frontier of the Colonial South: A Correlation of Documentary and Archaeological Data. Southeastern Archaeology, 27, 1-30.

Hoard, R. J., O’Brien, M. J., Khorashany, M. G. and Gopalartnam, V. S. 1995. A materials-science approach to understanding limestone-tempered pottery from the Midwestern United States. Journal of Archaeological Science, 22, 823-832.

Lieb, B. R., 2004. Chickasaw Pottery. In: Johnson, J., Ethridge, R., Lieb, B., Scott, S., Jackson, H., Jacobi, K. and Raush, D. C. (eds.) The Chickasaw: Economics, Politics, and Social Organization in the early 18th Century. Oxford: Center for Archaeological Research, University of Mississippi.

Lowe, E. N., 1920. Mississippi State Geological Survey. Bulletin 16. State Geological Association.

Mann, C. B. J., 1983. Classification of Ceramics from the Lubbub Creek Archaeological Locality. In: C. S. Peebles (ed.) Prehistoric Agricultural Communities in West Central Alabama: Studies of Material Remains from the Lubbub Creek Archaeological Locality. University of Michigan, 2137. Submitted to the U.S. Army Corps of Engineers, Mobile District. Copies available from National Technical Information Services, Springfield, Virginia.

Maritan, L., Mazzoli, C. and Freestone, I., 2007. Modelling Changes in Mollusc Shell Internal Microstructure During Firing: Implications for Temperature Estimation in Shell-Bearing Pottery. Archaeometry, 49(3), 529-541.

Million, M. G., 1975. Research Design for the Aboriginal Ceramic Industries of the Cache River Basin". In: M. B. Schiffer and J. H. House. (eds.) The Cache River Archeological Project: An Experiment in Contract Archeology. Fayetteville, Arkansas: Arkansas Archeological Survey, Publications in Archeology, Research Series No. 8, 217-222.

Moore, W.H. and Bicker, A.R., Jr., 1969. Geologic map of Mississippi. Mississippi Geological Survey. 
Muller, N.S., 2017. Mechanical and thermal properties. In: A. Hunt (ed.), The Oxford handbook of archaeological ceramic analysis. Oxford: Oxford University Press, 603-624.

Peacock, E., 2002. Geological Sourcing of Sand Used for Mississippian House Floors at the Lyon's Bluff Site in Oktibbeha County, Mississippi. Paper presented at the Mississippi Archaeological Association annual meeting. Columbus, Mississippi.

Peacock, E. and Hogue, S. H., 2005. A New Series of Absolute Dates from Lyon's Bluff (22OK520), North Mississippi. Southeastern Archaeology, 23, 46-58.

Peacock, E., Neff, H., Rafferty, J. and Meaker, T., 2007. Using Laser Ablation-Inductively Coupled Plasma-Mass Spectrometry (LA-ICP-MS) to Source Shell-Tempered Pottery: A Pilot Study from North Mississippi. Southern Archaeology, 26, 319-329.

Peacock, E., Palmer, R. A., Xia, Y., Bacon-Schulte, W., Carlock, B. and Smith, J., 2010. Chemical Sourcing of a Prehistoric Freshwater Shell Artifact Using Laser Ablation Inductively Coupled Plasma Mass Spectrometry. Archaeology of Eastern North America, 38, 91-99.

Perttula, T., Trubitt, M. B., and Girard, J.S., 2012. The Use of Shell-Tempered Pottery in the Caddo Area of the Southeastern United States. Southeastern Archaeology, 30, 242-267.

Picon, M., 1995, Grises et grises: quelques réflexions sur les céramiques cuites en mode B, in Actas das las Jornadas de Cerâmica Medieval e Pós-Medieval. Métodos e resultados para o seu estudo (1992), 283-292, Câmara Municipal de Tondela, Porto.

Quinn, P.S., 2013. Ceramic Petrography: The Interpretation of Archaeological Pottery and Related Artefacts in Thin Section. Oxford: Archaeopress.

Quinn, P.S. and Burton, M., 2015. Ceramic distribution, migration and cultural interaction among late prehistoric (ca. 1300-200 B.P.) hunter-gatherers in the San Diego region, Southern California. Journal of Archaeological Science Reports, 5, 285-295.

Quinn, P.S., Day, P.M., Kilikoglou, V., 2010. Keeping an eye on your pots: the provenance of Neolithic ceramics from Cyclops cave on the Island of Youra, Greece. Journal of Archaeological Science, 37, 1042-1052.

Rafferty, J., 1995. A Seriation of Historic Period Aboriginal Pottery from Northeast Mississippi. Journal of Alabama Archaeology, 41, 180-207.

Rafferty, J. and Peacock, E., 2008. The Spread of Shell Tempering in the Mississippi Prairie. Southeastern Archaeology, 27(2), 253-264.

Rafferty, J. and Peacock, E., 2009. Frequency Seriation and Settlement Patterning: A Response to McNutt. Southeastern Archaeology, 28, 271-274. 
Rice, P.M., 1987. Pottery Analysis: a sourcebook. Chicago: University of Chicago Press. Rye, O. S., 1976. Keeping temperature under control: materials and the manufacture of Papuan pottery. Archaeology and Physical Anthropology in Oceania, 11, 106-137.

Rogers M.J. 1936. Yuman Pottery Making. San Diego Museum Papers 2. Museum of Man, San Diego.

Roper, D., 2011. Shell-Tempered Pottery on the Central Plains. Southeastern Archaeology, 30(2), 268-287.

Rye, O. S., 1976. Keeping temperature under control: materials and the manufacture of Papuan pottery. Archaeology and Physical Anthropology in Oceania, 11, 106-37.

Smith, A., 2017. Sherds with Style: A Ceramic Analysis from a Protohistoric Site in Oktibbeha County, Mississippi. Unpublished Masters Thesis, University of Mississippi.

Speck, F. G., 1928. Chapters on Ethnology of the Powhatan Tribes of Virginia. Indian Notes and Monographs, 1(5), 227-455.

Stenzel, H.B., 1971. Oysters. In: R.C. Moore (ed.) Treatise on Invertebrate Paleontology Part N, Vol. 3, Mollusca 6, Bivalvia. Boulder, Colorado: Geological Society of America, N953-N1224.

Steponaitis, V. P., 1983. Ceramics, Chronology, and Community Patterns: An Archaeological Study at Moundville. New York, New York: Academic Press.

Sun, J. and Bhushan, B., 2012. Hierarchical Structure and Mechanical Properties of Nacre: A Review. RSC Advances, 2, 7617-7632.

Travé, E., Quinn, P.S., López, M.D., Padilla, J.I., 2014. One hundred sherds of grey: Compositional and Technological Characterization of Medieval Greyware Pottery Production at Cabrera D’Anoia, Catalonia, Spain. Archaeological and Anthropological Sciences, 6, 397-410.

Trinkley, E., 1994. Analysis of Paleoethnobotanical Samples from a Mississippian Farmstead, 220K595, Oktibbeha County, Mississippi. Columbia, South Carolina: Chicora Foundation, Inc. U.S. Geological Survey, (2018). Mineral Resources Data System: U.S. Geological Survey database. [online] Available at: https://mrdata.usgs.gov/ [Accessed 1 August 2018].

Tykot, R.H., 2016. Using Nondestructive Portable X-ray Fluorescence Spectrometers on Stone, Ceramics, Metals, and Other Materials in Museums: Advantages and Limitations. Applied Spectroscopy, 70, 42-56.

Whitbread, I. K., 1989. A Proposal for the Systematic Description of Thin Sections Towards the Study of Ancient Ceramic Technology. In: Y. Maniatis (ed.) Archaeometry: Proceedings of the 25th International Symposium. Elsevier, Amsterdam,127-138. 
Wilke, D., Rauch, D. and Rauch, P., 2017. Is Non-destructive Provenancing of Pottery Possible With Just a Few Discriminative Trace Elements? STAR: Science and Technology of Archaeological Research, DOI: 10.1080/20548923.2016.1209030.

Yao, Z., Xia, M., Li, H., Chen, T., Ye, Y. and Zheng, H., 2013. Bivalve shell: not an abundant useless waste but a functional and versatile biomaterial. Critical Reviews in Environmental Science and Technology, 44(22), 2501-2530.

\section{Appendix Captions}

Appendix 1. Certified values for 13 rock, ore, sediment, soil, and ceramic reference materials used to assess the performance of UCL Ceramics 1 high calcium pXRF calibration. Values given in percentage weight.

Appendix 2. Accuracy of UCL Ceramics 1 pXRF calibration over the range of concentrations found in earthenware archaeological ceramics, based on 14 reference materials in Appendix 1. Accuracy calculated using the formula (measured-certified)/certified)x100 and given in percentage relative error. Ceramics compositional range determined using data from Day et al. (2011), Quinn and Burton (2015), Quinn et al. (2010), and Trave et al. (2014).

Appendix 3. Data quality of SEM-EDS based on the analysis of three basalt certified reference materials BHVO (Hawaiian Volcano Observatory), BCR (Columbia River), and BIR (Icelandic). Data presented as percentage weight oxides. 